Jurnal Keperawatan Padjadjaran

ISSN 2338-5324 (print)

ISSN 2442-7276 (online)

Online di http://jkp.fkep.unpad.ac.id

DOI : $10.24198 / \mathrm{jkp}$

\title{
The Correlation of Socio Demographic and Knowledge Factors Toward Therapy Options among Breast Cancer Patients
}

\author{
Laili Rahayuwati*, Kusman Ibrahim, Ikeu Nurhidayah, Sri Hendrawati \\ Faculty of Nursing, Universitas Padjadjaran, Bandung, Indonesia \\ Corresponding Email: laili.rahayuwati@unpad.ac.id
}

Submitted: 16-12-2020 Accepted: 31-12-2020 Published: 31-12-2020

\begin{abstract}
The high prevalence and incidence of breast cancer patients poses a threat to the life quality of Indonesian women. Beside the patient's condition, therapy options are also the factors faced by both the patients and their families. This research aimed at analyzing socio demographic and knowledge factors relating to therapy options of breast cancer patients. A cross-sectional research was conducted directly to the people (community-based and hospital-based) from 198 cancer patients in the main region, West Java Province. Data were collected through face-to-face interviews with patients, with or without their family. The data were analyzed using the Chi-Square test to yield a correlation between socio demographic and knowledge factors on therapy options. The findings of this research showed that there was a significant relationship between socio demographic factor (physical condition $(p=0.002)$, emotional condition $(p=0.000)$, patient's age $(p=0.000)$, marital status $(p=0.000)$, family status $(\mathrm{p}=0.000)$, faith $(\mathrm{p}=0.032)$, and income $(\mathrm{p}=0.026))$ and the knowledge factor (knowledge about illness $(p=0.045)$, the cause of breast cancer $(p=0.000)$, indications and early symptoms of breast cancer $(p=0.014)$, indications and symptoms during breast cancer therapy $(\mathrm{p}=0.000)$, therapy for breast cancer $(\mathrm{p}=0.000)$, and treatment on indications and symptoms $(\mathrm{p}=0.000)$ ) with therapy options. Therapy options can be impacted by socio demographic and knowledge factors, although considerations from family also play a key role. In this context, the nurse plays the role as an advocate to raise awareness on the importance of treatment to healthcare facilities, thus the people can make a well-informed choice on their therapy. The uniqueness of the research showed the characteristic of patients, and therapies option in the multi medical system in Indonesia.
\end{abstract}

Keywords: Breast cancer patients, knowledge factor, socio demographic, therapy options. 
Laili Rahayuwati: The Correlation of Socio Demographic and Knowledge Factors Towards Therapy Options

\section{Introduction}

Cancer poses around 8.2 million deaths every year and is the second highest cause of death worldwide. For men, the biggest cause of death is lung cancer, while for women, it is breast cancer. As much as $75 \%$ of breast cancer patients in the world have been identified in low- and middle-income countries (Torre et al., 2015; World Health Organization (WHO), 2017).

Breast cancer is one of the cancers with the most common types in Indonesia. It is estimated that the incidence rate in Indonesia is $12 / 100.000$ women, more than $80 \%$ cases were found in an advanced stage, where a proper treatment was nearly impossible (Ministry of Health Republic of Indonesia, 2017). The high incidence and mortality rate by breast cancer shows that it requires a serious concern. However, the real-life situation offers a variety of therapy options, from conventional or modern, traditional and complementary.

One of the factors relating to the quality of life of the patients is determining the type of treatment to be done by patients. A study discovered that an early decision for breast cancer patients was to undergo traditional (alternative) treatment, and the patient would undergo conventional treatment if the former doesn't make any change. This is different for the healthcare providers; they believe that conventional treatment is the best choice. When patients are undergoing conventional (modern) treatment, there are those who out for the traditional one as well (Goldhirsch et al., 2013; Rahayuwati, Ibrahim, \& Mardiah, 2016).

Based on a research by the Basic Health Research (Riskesdas) in 2013, 6,701 breast cancer patients were found in West Java. Meanwhile, in Bandung City, based on the data from Health Agency Bandung City in the past 3 years, the number of breast cancer patients are fluctuating. While in 2014, the number of the patients were 239, in 2015, it rose to 523. Thankfully, in 2016 the number went down to 459 (Ministry of Health Republic of Indonesia, 2017).

Most breast cancer patients become aware of their illness when it hits the advanced stage. This leads to the decreasing quality of life, physically, psychologically, socially, and spiritually. Modern therapy for advanced-stage breast cancer patients is considered arduous to perform because of the unsatisfactory result (Manuaba, 2008). The side effects of modern therapy include fatigue, anemia, hot flashes, skin problems, and psychological distress such as anxiety and depression during and after therapy. As a result, to maximize the treatment and reduce its side effects, breast cancer patients often use complementary therapy (Saquib et al., 2012).

Complementary therapy, as an addition to modern therapy, functions as a supporting treatment to control the symptoms, increase quality of life, and contribute to the patient's overall treatment (Saini et al., 2011). Previous studies saw a set of secondary data in Health Agency Bandung City where they found that the people tend to look for complementary therapy due to its effectiveness. They believe that it assures a 100 percent recovery to the patient, although only few research shows its effect in general. An interview with the program organizer of non-communicable diseases in Health Agency Bandung said that complementary therapy in Indonesia, especially in Bandung, has a particularly high demand. According to the regulation from the Ministry of Health number 1109/MENKES/ PER/IX/2007 regarding complementary and alternative treatment, it is imperative that all traditional treatments be listed into the Head of Health Agency to get a letter of registration of medical staff for the complementaryalternative treatment called SBR-TPKA (Ministry of Health Republic of Indonesia, 2015).

The development of the use of modern and complementary therapy is closely related to the decision-making process as the expected primary action. Further, every human being with the intention to self-care as part of their basic needs. This theory explains about therapeutic self-care demand--that is, any actions necessary to fulfill self-care. Breast cancer patients take the decision to use either modern or modern and complementary therapy. These conditions highly impact their decision, including age, marital status, education level, occupation, and family support (Gerber, Scholz, Reimer, Briese, \& 
Laili Rahayuwati: The Correlation of Socio Demographic and Knowledge Factors Towards Therapy Options

Janni, 2006).

From the previous explanation, the most popular modern therapy is chemotherapy. Several research states that the combination between modern and complementary therapy can increase the quality of life of breast cancer patients. There are, however, some others with opposing thesis statements (Saini et al., 2011). The result of the introductory study also shows the number of complementary therapy for breast cancer in West Java, but there is no research regarding its use.

Rahayuwati,Ibrahim, and Komariah(2017) studied on qualitative treatment options for breast cancer patients during chemotherapy in Indonesia. The purpose of this study was to explore the life experiences of breast cancer patients in the choice of therapies. A sample of 17 participants was selected by purposive sampling and data collection using in-depth interviews. The results of the study stated that there were 4 dominant themes, namely (1) Cancer is a concept and part of subjective socio-legal legality; 2) Selection of the type of therapy must be accepted/agreed upon by the family and social support system; 3 ) Cancer conditions give meaning to the patient's life; and (4) Hope for recovery.

Research Wang et al. (2015) in China about the relationship status of social support, health insurance and clinical factors with the quality of life of Chinese women with breast cancer showed that the social support of family members, friends and neighbors are high, high income, and treatment with traditional Chinese medicine affects significantly to the quality of life of breast cancer patients.

Furthermore, therapy options can also be impacted by the distance of the therapy place to the people (physically and socially), affordable price, quality of service, and etc. (Mamik, 2010). According to Gerber et al. (2006), other factors include therapy service provider, the cost of the therapy, and distance. On the other hand, the two factors from the people who use the therapy include education level and socioeconomic status. There are also socio demographic and knowledge factors. The former focuses on the physical condition, emotional condition, age, marital status, family status, ethnicity, faith, residence, education, occupation, income, therapy period, family medical records, healthcare provider, and insurance. The latter focuses on information source, knowledge of illness, the cause of breast cancer, early symptoms of breast cancer, indications and symptoms during therapy, the best therapy, action on the symptoms, and the risks of breast cancer. This research aimed at describing socio demographic and knowledge factors relating to therapy options of breast cancer patients.

\section{Method}

The research was designed quantitatively, including the analysis of socio demographic and knowledge factors related to therapy options of breast cancer patients. The population was derived from several areas in Indonesia, including West Java province. The samples were obtained from medical data in the hospital where the patients underwent therapy and treatment. The number of samples was determined based on the number of population, assuming that the cancer patients were 2034 in number. Therefore, this research used the Slovin formula to get $\alpha=$ 0.05 , resulting in 300 patients as the samples. The sampling technique used was random sampling technique. However, due to the time constraints, the final samples were only 198.

Data were collected through instrument filling and interviews to breast cancer patients involving questionnaires (with the assistance of some on-field staff). Further, the instruments were tested to adjust the content and the language so that it matches with that of the patient's. The validation of instruments was done through Product Moment test and the reliability measurement was done using Cronbach's Alpha in SPSS software version 22.0 with license. Cronbach's Alpha was used to produce the average correlation between items and the number of items.

The quantitative data was processed using SPSS software version 22.0 with license. These sets of data included independent variables such as socio-demographic factor (the physical condition, emotional condition, age, marital status, family status, ethnicity, faith, residence, education, occupation, income, therapy period, family medical records, healthcare provider, and insurance) 
and the knowledge factor (information source, knowledge of illness, the cause of breast cancer, early symptoms of breast cancer, indications and symptoms during therapy, the best therapy, action on the symptoms, and the risk of breast cancer). Meanwhile, the bound variable is the therapy option of whether to undergo any therapy at all, go to modern therapy, or go to modern and complementary therapy, which will later be referred to as complementary therapy. Bivariate quantitative analysis used the ChiSquare test.

Ethical consideration of this research has been consented by the Committee of Ethics

on Health Research in Faculty of Medicine Universitas Padjadjaran with number 277/ UN6.C1.3.2/KEPK/PN/2015. This consent is adjusted with the objectives and the subjects in the research such as breast cancer patients and healthcare professionals. The preparation of informed consent was done to fulfill that consideration, with the objective to provide the right information to the subject. Further, this consideration has the privilege to be involved in the research voluntarily or not.

\section{Results}

Table 1 Distribution of Frequency on Socio Demographic Factor of Breast Cancer Patients $(\mathrm{n}=198$ people)

\begin{tabular}{|c|c|c|}
\hline Socio Demographic Factor & Frequency & Percentage $(\%)$ \\
\hline \multicolumn{3}{|l|}{ Physical Condition } \\
\hline Stage I & 11 & 5.56 \\
\hline Stage II & 62 & 31.30 \\
\hline Stage III & 72 & 36.36 \\
\hline Stage IV & 29 & 14.65 \\
\hline Stage VI & 13 & 6.57 \\
\hline Other Stages & 11 & 5.56 \\
\hline \multicolumn{3}{|l|}{ Emotional Condition } \\
\hline Denial & 4 & 2.02 \\
\hline Anger & 4 & 2.02 \\
\hline Bargaining & 11 & 5.56 \\
\hline Depression & 13 & 6.57 \\
\hline Acceptance & 166 & 83.83 \\
\hline \multicolumn{3}{|l|}{ Patient's Age } \\
\hline $15-24$ years old & 3 & 1.51 \\
\hline $25-34$ years old & 25 & 12.63 \\
\hline $35-44$ years old & 58 & 29.29 \\
\hline $45-54$ years old & 64 & 32.32 \\
\hline 55-64 years old & 41 & 20.71 \\
\hline$>64$ years old & 7 & 3.54 \\
\hline \multicolumn{3}{|l|}{ Marital Status } \\
\hline Single & 24 & 12.12 \\
\hline Married & 136 & 68.69 \\
\hline Widowed & 38 & 19.19 \\
\hline \multicolumn{3}{|l|}{ Ethnicity } \\
\hline Sundanese & 169 & 85.35 \\
\hline Javanese & 28 & 14.14 \\
\hline Padangnese & 1 & 0.51 \\
\hline
\end{tabular}


Laili Rahayuwati: The Correlation of Socio Demographic and Knowledge Factors Towards Therapy Options

\begin{tabular}{|c|c|c|}
\hline \multicolumn{3}{|l|}{ Residence } \\
\hline Urban & 124 & 62.63 \\
\hline Rural & 74 & 37.37 \\
\hline \multicolumn{3}{|l|}{ Family Status } \\
\hline Child & 20 & 10.10 \\
\hline Wife & 156 & 78.79 \\
\hline Others & 22 & 11.11 \\
\hline \multicolumn{3}{|l|}{ Faith } \\
\hline Islam & 196 & 98.98 \\
\hline Protestant & 1 & 0.51 \\
\hline Catholic & 1 & 0.51 \\
\hline \multicolumn{3}{|l|}{ Education } \\
\hline Uneducated & 2 & 1.01 \\
\hline Elementary school & 25 & 12.63 \\
\hline Elementary school graduate & 49 & 24.75 \\
\hline Middle school & 7 & 3.54 \\
\hline Middle school graduate & 38 & 19.19 \\
\hline High school & 15 & 7.58 \\
\hline High school graduate & 53 & 26.77 \\
\hline Undergraduate & 1 & 0.51 \\
\hline Bachelor & 8 & 4.04 \\
\hline \multicolumn{3}{|l|}{ Occupation } \\
\hline Unemployed & 9 & 4.55 \\
\hline Housewife & 145 & 73.23 \\
\hline Farmer & 7 & 3.54 \\
\hline Labour & 6 & 3.03 \\
\hline Self-Employed & 12 & 6.06 \\
\hline Private Employee & 12 & 6.06 \\
\hline Civil Worker & 4 & 2.02 \\
\hline Teacher & 2 & 1.01 \\
\hline Nurse & 1 & 0.51 \\
\hline \multicolumn{3}{|l|}{ Income } \\
\hline$<\operatorname{Rp} 500.000$ & 48 & 24.24 \\
\hline Rp 500.000 - Rp 1.000 .000 & 40 & 20.20 \\
\hline $\operatorname{Rp} 1.000 .000-\operatorname{Rp} 1.500 .000$ & 53 & 26.77 \\
\hline Rp 1.500.000 - Rp 2.000.000 & 17 & 8.59 \\
\hline$>\operatorname{Rp} 2.000 .000$ & 40 & 20.20 \\
\hline \multicolumn{3}{|l|}{ Therapy Period } \\
\hline$<1$ years & 180 & 90.90 \\
\hline $1-3$ years & 17 & 8.59 \\
\hline $3-5$ years & 1 & 0.51 \\
\hline Family Medical Record & & \\
\hline
\end{tabular}


Laili Rahayuwati: The Correlation of Socio Demographic and Knowledge Factors Towards Therapy Options

\begin{tabular}{lcc}
\hline Cancer-stricken & 145 & 73.23 \\
Cancer-free & 53 & 26.77 \\
Family Type & & \\
Nuclear Family & 130 & 65.66 \\
Big Family & 39 & 19.70 \\
Others & 29 & 14.65 \\
Caregiver & & \\
Self & 92 & 46.46 \\
Husband & 67 & 33.84 \\
Relatives & 7 & 3.54 \\
Neighbors & 1 & 0.51 \\
\hline
\end{tabular}

Table 2 Distribution of Frequency of Knowledge Factor on Respondents Regarding Breast Cancer ( $n=198$ people)

\begin{tabular}{|c|c|c|}
\hline Knowledge Factor & Frequency & Percentage $(\%)$ \\
\hline \multicolumn{3}{|l|}{ Information Source } \\
\hline Books & 1 & 0.51 \\
\hline Electronic media & 16 & 8.08 \\
\hline Healthcare staff & 163 & 82.32 \\
\hline Friends & 7 & 3.54 \\
\hline Neighbors & 6 & 3.03 \\
\hline Others & 5 & 2.53 \\
\hline \multicolumn{3}{|l|}{ Knowledge about Illness } \\
\hline Informed & 139 & 70.20 \\
\hline Uninformed & 59 & 29.80 \\
\hline \multicolumn{3}{|l|}{ Cause of breast cancer } \\
\hline Informed & 118 & 59.60 \\
\hline Uninformed & 80 & 40.40 \\
\hline \multicolumn{3}{|l|}{ Indication and early symptoms } \\
\hline Pain & 67 & 33.84 \\
\hline Swelling & 36 & 18.18 \\
\hline Wound & 3 & 1.52 \\
\hline Others & 96 & 46.46 \\
\hline \multicolumn{3}{|c|}{$\begin{array}{l}\text { Indication and early symptoms } \\
\text { during therapy }\end{array}$} \\
\hline Nausea and vomit & 42 & 21.21 \\
\hline Swelling & 81 & 40.91 \\
\hline Wound & 15 & 7.58 \\
\hline Pain & 41 & 20.71 \\
\hline Fatigue & 3 & 1.52 \\
\hline Digestive problems & 2 & 1.01 \\
\hline None & 14 & 7.07 \\
\hline
\end{tabular}


Laili Rahayuwati: The Correlation of Socio Demographic and Knowledge Factors Towards Therapy Options

\begin{tabular}{lcc}
\hline Best therapy for breast cancer & 183 & \\
Informed & 15 & 92.42 \\
Uninformed & & 7.58 \\
Actions on cancer symptoms & 21 & 10.61 \\
None & 8 & 4.04 \\
Home therapy & 76 & 38.38 \\
Traditional therapy & 93 & 46.97 \\
Modern therapy & & \\
Risks of breast cancer & 145 & 73.23 \\
Informed & 53 & 26.77 \\
Uninformed & & \\
\hline
\end{tabular}

Table 3 Distribution and Frequency of Therapy Options of Breast Cancer Patients $(n=198$ people)

\begin{tabular}{lcc}
\hline \multicolumn{1}{c}{ Therapy Options } & Frequency (f) & Percentage (\%) \\
\hline None & $\mathbf{4}$ & $\mathbf{2 . 0 2}$ \\
Traditional Therapy & 29 & 14.65 \\
Modern Therapy & 137 & 69.19 \\
Complementary Therapy & 28 & 14.14 \\
\hline
\end{tabular}

Table 4 Result of Correlation Test on Socio Demographic Factor to Therapy Options

\begin{tabular}{lc}
\hline \multicolumn{1}{c}{ Socio Demographic Factor } & Therapy Options \\
\hline Physical Condition & $\mathrm{p}=0.002$ \\
Emotional Condition & $\mathrm{p}=0.000$ \\
Patient's Age & $\mathrm{p}=0.000$ \\
Marital Status & $\mathrm{p}=0.000$ \\
Ethnicity & $\mathrm{p}=0.349$ \\
Residence & $\mathrm{p}=0.275$ \\
Family Status & $\mathrm{p}=0.000$ \\
Faith & $\mathrm{p}=0.032$ \\
Education & $\mathrm{p}=0.464$ \\
Occupation & $\mathrm{p}=0.622$ \\
Income & $\mathrm{p}=0.026$ \\
Therapy Period & $\mathrm{p}=0.914$ \\
Family Medical Record & $\mathrm{p}=0.099$ \\
Family Type & $\mathrm{p}=0.142$ \\
Caregiver & $\mathrm{p}=0.359$ \\
\hline
\end{tabular}


Laili Rahayuwati: The Correlation of Socio Demographic and Knowledge Factors Towards Therapy Options

Table 5 Test Result of Correlation between Knowledge Factor of Breast Cancer Patients and Therapy Options ( $\mathrm{n}=198$ people)

\begin{tabular}{lc}
\hline \multicolumn{1}{c}{ Knowledge Factor } & Therapy Options \\
\hline Information Source & $\mathrm{p}=0.422$ \\
Knowledge about illness & $\mathrm{p}=0.045$ \\
Cause of breast cancer & $\mathrm{p}=0.000$ \\
Indication and symptoms & $\mathrm{p}=0.014$ \\
Indication and symptoms during therapy & $\mathrm{p}=0.000$ \\
Therapy for breast cancer & $\mathrm{p}=0.000$ \\
Actions on indication and symptoms & $\mathrm{p}=0.000$ \\
Risks of breast cancer & $\mathrm{p}=0.537$ \\
\hline
\end{tabular}

Table 1 shows that of the patient's physical condition, 72 respondents $(36.36 \%)$ are in stage-three cancer. From the emotional condition, 166 respondents $(83.83 \%)$ are in the acceptance stage. Age-wise, 64 respondents $(32.32 \%)$ are $45-54$ years old. 136 respondents $(69.69 \%)$ are married. 169 $(85.35 \%)$ are Sundanese and $196(98.98 \%)$ are Muslims. $124(62.23 \%)$ live in the city area. $156(78.79 \%)$ are wife in a family status. Education-wise, 53 respondents $(26.77 \%)$ are high school graduates and $145(73.23 \%)$ are housewives. Income-wise, another 53 has an income around $\mathrm{Rp} 1.000 .000$ - Rp 1.500.000. There are as many 180 respondents $(90.90 \%)$ have undergone therapy for $<1$ year and 145 $(73.23 \%)$ have contracted cancer before. There are as many $130(65.66 \%)$ live with nuclear families. During their illness, 92 $(46.46 \%)$ can take care of themselves.

Table 2 shows the knowledge factor of the patient regarding breast cancer. Based on the information source, 198 respondents $(100 \%)$ are well-informed about breast cancer and 163 of them (82.32\%) are informed from the healthcare providers. On the other hand, 139 respondents $(70.20 \%)$ are also well-informed while 118 others $(59.60 \%)$ know the cause of the cancer. While all respondents are able to identify early symptoms of breast cancer, $106(53.54 \%)$ experience pain, swelling, and wound as their first identification of breast cancer. There are 184 respondents $(92.93 \%)$ experience indication and symptoms during breast cancer therapy, and $183(92.42 \%)$ understand different types of breast cancer therapy. Table 2 also shows that 93 respondents (46.97\%) know modern therapy as cancer treatment, and 145 others $(73.23 \%)$ understand the risk of the cancer.

Table 3 shows the therapy option from the respondents. It shows that 137 of them $(69.19 \%)$ choose to undergo modern therapy, while only $4(2.02 \%)$ choose not to undergo any therapy. There are 29 others $(14.65 \%)$ opt out for traditional therapy, and 28 (14.14) choose complementary therapy.

The result of the correlation rest on table 4 shows that there is a relationship between physical condition $(\mathrm{p}=0.002)$, emotional condition $(\mathrm{p}=0.0000)$, patient's age $(\mathrm{p}=$ $0.000)$, marital status $(\mathrm{p}=0.000)$, family status $(\mathrm{p}=0.000)$, faith $(\mathrm{p}=0.032)$, and income $(\mathrm{p}=$ 0.026 ) with the respondent's therapy option. However, there is no relationship between ethnicity $(p=0.349)$, residence $(p=0.275)$, education level $(\mathrm{p}=0.464)$, occupation $(\mathrm{p}=$ $0.622)$, therapy period $(\mathrm{p}=0.914)$, family's medical record $(\mathrm{p}=0.099)$, family type $(\mathrm{p}=$ $0.142)$, and the caregiver $(\mathrm{p}=0.359)$.

The correlation test result on table 5 shows there is a relationship between knowledge of the illness $(p=0.045)$, cause of breast cancer $(p=0.000)$, indication and early symptoms of breast cancer $(p=0.000)$, indication and symptoms during therapy $(p=0.000)$, breast cancer therapy $(p=0.000)$, and actions on indication and symptoms $(p=0.000)$ and the respondent's therapy options. However, there is no relationship between information source $(p=0.422)$ and the risk of contracting breast cancer $(p=0.537)$ and the respondent's therapy options.

\section{Discussion}

The result of this research shows that there 
are different therapy options of breast cancer patients. While 137 respondents $(69.19 \%)$ prefer modern therapy, 29 others $(14.65 \%)$ choose traditional therapy, 28 (14.14\%) complementary, and $4(2.02 \%)$ no therapy at all. This research shows that more patients choose modern therapy over complementary. This result is not in line with Saquib et al. (2012) saying that complementary therapy is most effective to maximize the treatment and reduce the side effects of modern therapy. This is strengthened by the fact that most patients prefer modern therapy largely because of the socio demographic and knowledge factor.

In line with this research, socio demographic factors related to therapy options include physical condition, emotional condition, patient's age, marital status, family status, faith, and income. Therapy options can be affected by the respondent's knowledge regarding breast cancer. According to information sources, all respondents are well-informed about breast cancer and nearly all get the information from healthcare staff. Besides, most respondents understand breast cancer in general and its causes. They know the indications and early symptoms, and nearly all experience pain, swelling, and wounds as the first indication of breast cancer. Nearly all respondents know the actions to cure breast cancer through modern therapy. The majority of the respondents also know the risk of having breast cancer. This result is because the longer they contract cancer, the more they get to learn about the illness. That's why some of them understand their illness and prefer modern therapy to others.

The patient's quality of life can be improved through modern therapy. Types of modern therapy include radiation, chemotherapy, surgery, and combination (Wolff et al., 2007). In Indonesia, chemotherapy is the most popular one for the lately diagnosed patients. Despite its positive impact, side effects also include nausea, decrease in red blood cells, decrease in white blood cells, decrease in thrombocytes, mucositis, hair loss, and nerve disorder (rarely) (National Cancer Institute, 2009). Chemotherapy is done periodically, typically six to eight cycles for optimum effects. The result of immunohistochemical check has several considerations for the given chemotherapy regimens (Ministry of
Health Republic of Indonesia, 2015). Most breast cancer patients have a medium quality of life after chemotherapy (Heydarnejad, Hassanpour Dehkordi, \& Solati Dehkordi, 2011; Pradana, 2012).

Apart from side effects, modern therapy for advanced stage breast cancer patients is difficult to perform and often leads to unsatisfactory results (Manuaba, 2008). That is why to optimize it, breast cancer patients also go for complementary therapy (Saquib et al., 2012). In this research, 28 respondents $(14.0 \%)$ prefer complementary therapy. According to Andrews (2009), complementary therapy is that which completes medical treatment given to the patients. Meanwhile, Crips and Taylor (2001) said that complementary therapy on cancer patients is the insertion of traditional therapy to the modern one. This term is known as the modality theory or an activity that adds to the healthcare service approach. Some others also call this therapy a holistic treatment. This is based on the type of therapy that impacts the individual in general--that is, his harmony to integrate mind, body, and soul in a unity (Neuhouser et al., 2017; Smith, Duell, \& Martin, 2004). Thus, it can be concluded that complementary therapy is a traditional therapy that adjoins the modern one to thoroughly integrate the patient's mind, body and soul as one function.

Saini et al. (2011) state that the value of quality of life of modern and complementary therapy users (herbal, special diet, bodybased practices) is lower than the users of modern therapy. Kang et al. (2011) said, however, that there is no significant difference between the patient's quality of life using modern and complementary therapy and the patients who choose modern therapy only. In fact, Gerber et al. (2006) show there is no significant relationship between modern and complementary therapy and the quality of life of breast cancer patients.

The correlation result test shows that there is a relationship between physical condition, emotional condition, patients age, marital status, family status, faith, and family income with the respondent's therapy options. The cancer has an impact on the women's emotional status, specifically at a reproductive age. During therapy, they get 
a unique individual experience (Rahayuwati et al., 2017). Breast cancer on women can impact her sense of existence and well-being, be it physically, emotionally, psychologically, socially, and spiritually. This will give a bigger impact when it comes to reproductive age because it has something to do with their sexuality and their position as a wife and a mother (Murtiwi, Nurachmah, \& Nuraini, 2014). That said, physical condition, emotional condition, and age can impact the women to choose the right therapy.

A research from Widyatuti (2008) also claims that there are patients who do not choose therapy. Every choice is a result of discussion and agreement with family or relatives. Most patients say that the husband is the most important person in the decisionmaking process, followed by siblings. In terms of therapy options, sometimes the support comes from the patient's adult offspring. Then, it all spirals down to informal public figures, such as religious teachers (ustadz), or an educated family member or doctors (Rahayuwati et al., 2017).

The research result from Rahayuwati et al. (2017) also claim that it is difficult, if not impossible, for patients to make their own decisions on which therapy to undergo without other people's consideration. This is because the social character and culture is a collective one, making all important decisions to be taken together. This also applies to when the patients are diagnosed of the illness and when they get chemotherapy, resulting in a decreasing physical abilities. This is where family presence and support is paramount.

In general, respondents choose therapy not based on modern therapy, but also alternative and complementary. A research done by Rahayuwati et al. (2016) and Goldhirsch et al. (2013) claim that the initial decision of breast cancer patients to undergo therapy is traditional or alternative, and they will undergo conventional therapy if the traditional one doesn't make any change. This is different for healthcare providers, where conventional therapy is deemed to be the best choice. However, in reality, when patients undergo modern therapy, some are also mixing it up with traditional medication.

The result of this research shows there is no relation between ethnicity, residence, education level, occupation, therapy period, family medical record, family type, and the caregiver with the respondent's therapy options. The demography shows that nearly all respondents are Sundanese and live in the city area, thus it is easier to access various health facilities. Education level is not impactful to the patient's therapy option, noting that all patients are well informed about breast cancer. Occupation-wise, most respondents are housewives. Therapy period also is not impactful because nearly all patients have undergone therapy for $<1$ year and they have a medical record of cancer, live with nuclear families, and can take care of themselves during therapy.

In this research, there is a relationship between knowledge of illness, cause of breast cancer, and indication and early symptoms of the cancer, symptoms during therapy, different types of therapy, and actions on symptoms with the respondent's therapy options. The more the patients know, the better the treatment will be (Notoatmodjo, 2007).

However, there is no relationship between information source and the risk of breast cancer with the respondent's therapy options. This may be because all respondents are well-informed from healthcare providers or books, electronic media, friends, neighbors, and other sources. That said, most patients are aware of the risk of cancer as well as the alternative therapy to undergo.

Noting the high demand of breast cancer patients for therapy, it is expected that nurses are able to do a holistic approach involving biological, psychological, social, cultural, and spiritual elements to patients. Specifically, it is suggested that nurses work closely to patients and can be in the patient's shoes. That said, nurses are the advocates to help patients determine which alternative or complementary medical therapy that is more suitable with the patient's faith and that offers a recommendation that meets the needs of breast cancer patients (Potter \& Perry, 2009).

\section{Conclusion}

Therapy options based on this research are impacted by socio demographic factors 
Laili Rahayuwati: The Correlation of Socio Demographic and Knowledge Factors Towards Therapy Options

(physical condition, emotional condition, patient's age, marital status, family status, faith, and income) and knowledge factor (knowledge about the illness, cause of breast cancer, indication and early symptoms of breast cancer, indication and symptoms during therapy, therapy for breast cancer, actions on the symptoms). The healthcare providers must raise awareness of the people about the importance of treatment to healthcare service facilities.

Therefore, the people can choose the right therapy. The modern therapy on patients is based on their needs and wants from patients and their family. Therapy options are also highly dependent on socio demographic and knowledge factors of the patient. The more they know, the better the decision they make to treat the illness. The speed of science and technology in healthcare demands the nurses to combine it with natural products suitable with the culture of the patients. In the end, it will result in an improved and sustainable service without neglecting the patient's culture and local wisdom.

\section{References}

Andrews, G. (2009). Buku ajar kesehatan reproduksi wanita. (Textbook on female reproductive health). EGC.

Crips, J., \& Taylor, C. (2001). Potter and Perry's fundamental of nursing. Australia: Mosby a Hartcourt Health Science Company.

Gerber, B., Scholz, C., Reimer, T., Briese, V., \& Janni, W. (2006). Complementary and alternative therapeutic approaches in patients with early breast cancer. A systematic review. Breast Cancer Research and Treatment, 95, 1999-209. https://doi.org/http://doi. org/10.1007/s10549005-9005-y

Goldhirsch, A., Winer, E. P., Coates, A. S., Gelber, R. D., Piccart-Gebhart, M., Thürlimann, B., ... Wood, W. C. (2013). Personalizing the treatment of women with early breast cancer: Highlights of the st gallen international expert consensus on the primary therapy of early breast Cancer 2013. Annals of Oncology, 24(9), 2206-2223. https://doi. org/10.1093/annonc/mdt303

Heydarnejad, M. S., Hassanpour Dehkordi, A., \& Solati Dehkordi, K. (2011). Factors affecting quality of life in cancer patients undergoing chemotherapy. African Health Sciences, 11(2), 266-270.

Kang, E., Yang, E. J., Kim, I. Y., Chung, S. A., Han, D. H., Ku, S. J., ... Kim. (2011). Complementary and alternative medicine use and assessment of quality of life in Korean breast cancer patients: A descriptive study. Supportive Care in Cancer, 20(3), 461-473. https://doi.org/10.1007/s00520-011-1094-z

Mamik. (2010). Organisasi dan manajemen pelayanan kesehatan dan kebidanan. (Organization and management of health and midwifery services). Prins Media.

Manuaba. (2008). Gawat-darurat obstetriginekologi \& obstetri-ginekologi sosial untuk profesi bidan. (Obstetrics-gynecology \& social obstetrics-gynecology emergencies for the midwifery profession). EGC.

Ministry of Health Republic of Indonesia. (2015). Pusat data dan informasi Kementerian Kesehatan RI. (Center for data and information of the Ministry of Health of the Republic of Indonesia). Ministry of Health Republic of Indonesia.

Ministry of Health Republic of Indonesia. (2017). Pusat data dan informasi Kementerian Kesehatan RI. (Center for data and information of the Ministry of Health of the Republic of Indonesia). Ministry of Health Republic of Indonesia.

Murtiwi, M., Nurachmah, E., \& Nuraini, T. (2014). Kualitas hidup klien kanker yang menerima pelayanan hospis atau homecare: Suatu analisis kuantitatif. (Quality of life for cancer clients receiving hospice or homecare services: A quantitative analysis). Jurnal Keperawatan Indonesia, 9(1), 13-18. https:// doi.org/10.7454/jki.v9i1.154

National Cancer Institute. (2009). Breast cancer. Retrieved July 21, 2020, from: http:// cancerweb.ncl.ac.uk/cancernet/100013.html. 
Neuhouser, M. L., Smith, A. W., George, S. M., Gibson, J. T., Baumgartner, K. B., Baumgartner, R., ... Ballard, R. (2017). Use of complementary and alternative medicine and breast cancer survival in the Health, Eating Activity and Lifestyle Study. Breast Cancer Res Treat., 160(3), 539-546. https:// doi.org/10.1007/s10549-016-4010-x.Use

Notoatmodjo. (2007). Promosi kesehatan dan ilmu perilaku. (Health promotion and behavioral science). Rineka Cipta.

Potter, P., \& Perry, A. (2009). Fundamental of nursing (3rd ed.). Elsevier Canada.

Pradana, I. P. W. (2012). Hubungan kualitas hidup dengan kebutuhan perawatan paliatif pada pasien kanker di RSUP Sanglah Denpasar. (The relationship between quality of life and the need for palliative care in cancer patients at Sanglah General Hospital, Denpasar). Fakultas Kedokteran Universitas Udayana, Bali, Indonesia.

Rahayuwati, L., Ibrahim, K., \& Komariah, M. (2017). Pilihan pengobatan pasien kanker payudara masa kemoterapi: Studi kasus. (Treatment options for breast cancer during chemotherapy: a case study). Jurnal Keperawatan Indonesia, 20(2), 118-127. https://doi.org/10.7454/jki.v20i2.478

Rahayuwati, L., Ibrahim, K., \& Mardiah, W. (2016). Health seeking behavior on breast cancer therapies: patients versus providers views. Journal of Community \& Public Health Nursing, 2(3), 2-6. https://doi. org/10.4172/2471-9846.1000129

Saini, A., Berruti, A., Capogna, S., Negro, M., Sguazzotti, E., Picci, R. L., ... Ostacoli, L. (2011). Prevalence of complementary/ alternative medicines (CAMs) in a cancer population in northern Italy receiving antineoplastic treatments and relationship with quality of life and psychometric features. Quality of Life Research, 20, 683690. https://doi.org/https://doi.org/10.1007/ s11136-010-9795-1
Saquib, J., Parker, B. A., Natarajan, L., Madlensky, L., Saquib, N., Patterson, R. E., ... Pierce, J. P. (2012). Prognosis following the use of complementary and alternative medicine in women diagnosed with breast cancer. Complementary Therapies in Medicine, 20(5), 283-290. https://doi. org/10.1016/j.ctim.2012.04.002

Smith, S. F., Duell, D. J., \& Martin, B. C. (2004). Clinical nursing skills: Basic to advanced skills. Pearson Prentice Hall.

Torre, L. A., Bray, F., Siegel, R. L., Ferlay, J., Lortet-tieulent, J., \& Jemal, A. (2015). Global cancer statistics, 2012. CA a Cancer J Clin, 65(2), 87-108. https://doi.org/10.3322/ caac. 21262

Wang, Y., Zhu, L., Yuan, F., Kang, L., Jia, Z., Chen, D., ... Feng, Z. (2015). The relationship between social support and quality of life: Evidence from a prospective study in chinese patients with esophageal carcinoma. Iranian Journal of Public Health, 44(12), 1603-1612.

Widyatuti, W. (2008). Terapi komplementer dalam keperawatan. (Complementary therapy in nursing) Jurnal Keperawatan Indonesia, 12(1), 53-57. https://doi.org/10.7454/jki. v12i1.200

Wolff, A. C., Hammond, M. E. H., Schwartz, J. N., Hagerty, K. L., Allred, D. C., Cote, R. J., ... Hayes, D. F. (2007). American Society of Clinical Oncology/College of American Pathologists Guideline Recommendations for Human Epidermal Growth Factor Receptor 2 Testing in Breast Cancer. Arch Pathol Lab Med, 131(1), 18-43. https://doi. org/10.1043/1543-2165(2007)131

World Health Organization (WHO). (2017). Cancer. Retrieved July 12, 2020, from http:// www.who.int/media centre/factsheets/fs297/ en/. 